\title{
Aplikasi Absensi Karyawan Berbasis Android Dengan Penerapan QR Code Disertai Foto Diri Dan Lokasi Sebagai Validasi: Studi Kasus PT.Selindo Alpha
}

\author{
Muhammad Himyar ${ }^{1}$, Muhamad Femy Mulya $^{2}$, Johny Hizkia Siringo Ringo $^{3}$ \\ ${ }^{1}$ Program Studi Teknik Informatika, Tanri Abeng University, Jakarta, Indonesia \\ m.himyar@student.tau.ac.id \\ ${ }^{2}$ Program Studi Sistem Informasi, Tanri Abeng University, Jakarta, Indonesia \\ femy.mulya@tau.ac.id \\ ${ }^{3}$ Program Studi Teknik Informatika, Tanri Abeng University, Jakarta, Indonesia \\ johny.hizkia@tau.ac.id
}

Diterima : 23 Februari 2021

Disetujui : 28 Maret 2021

\begin{abstract}
Salah satu komponen utama dalam dunia kerja adalah absensi atau daftar hadir. Dengan kehadiran tersebut, pekerjaan di suatu perusahaan dapat berjalan secara terstruktur dan teratur. Seiring dengan mobilitas yang tinggi, penggunaan smartphone kini juga dimanfaatkan untuk menunjang aktivitas kerja, salah satunya untuk melakukan absensi. Namun, belum banyak perusahaan yang menggunakan teknologi ini di perusahaannya. Penelitian ini bertujuan untuk membangun sistem absensi pegawai otomatis berbasis android dengan menggunakan QR code disertai foto diri dan LBS (Location Based System) online. Pada aplikasi ini memungkinkan pengguna untuk mengisi absensi dengan mudah dan dapat digunakan kapan saja, sehingga karyawan yang memiliki waktu terbatas dan tidak mempunyai waktu untuk mengisi form daftar hadir dapat dengan mudah mengisi daftar absensi. Aplikasi ini dikembangkan dengan menerapkan model agile scrum dan dirancang menggunakan UML dan bahasa pemrograman berbasis Java dan untuk proses pengujian menggunakan pengujian black box. Penelitian dilakukan dengan pengumpulan data melalui studi pustaka. Penelitian ini menghasilkan aplikasi yang sudah teruji dari segi kegunaan dan dinyatakan valid atau sesuai dengan kebutuhan pengguna.
\end{abstract}

Keyword: Attendance, Android, QR Code, Location Base System

\section{PENDAHULUAN}

\section{A. Latar Belakang Masalah}

Perkembangan teknologi semakin cepat dan pesat, khususnya pada teknologi informasi dan komunikasi. Dengan semakin majunya perkembangan teknologi informasi tersebut, membuat setiap orang mampu menciptakan berbagai macam peralatan sebagai alat bantu dalam melaksanakan aktivitas yang mendukung produktifitas pada suatu pekerjaan. Dengan berbagai macam jenis aktivitas yang semakin kompleks dan padat, membuat sebagian orang memiliki tingkat mobilitas yang sangat tinggi. Salah satu perangkat mobile yang paling pesat perkembangannya saat ini adalah handphone, dimana hampir setiap individu memilikinya. Berbagai macam fitur pada Handphone telah banyak ditanamkan, seperti digunakan untuk pengolah image/gambar dan video, pengolah dokumen digital dan lain sebagainya. Hal ini tidak lepas dari penggunaan Operating System pada Handphone. Seperti halnya pada computer, handphone pun dapat di install bermacam-macam aplikasi yang dibutuhkan.

Meskipun PT. Selindo Alpha sudah menggunakan tekologi canggih dalam kegiatan sehari-hari namun, perusahaan ini belum mempunyai sistem absensi yang berbasis komputasi. Hal paling mendasar dalam suatu pekerjaan adalah absensi atau daftar kehadiran, dimana hal tersebut dijadikan sebagai acuan untuk menilai kinerja, keaktifan dan kerajinan pegawai. Semua karyawan PT. Selindo Alpha masih melakukan absensi secara manual yaitu dengan melapor kepada masing-masing Team Leader. 
Setelah itu, setiap bulan Team Leader akan mengirimkan hasil rekap absensi setiap anggota tim kepada HRD (Personalia) dalam bentuk file excel. Mengelola data absensi karyawan dengan akurat adalah tugas yang sulit, terutama dalam mengumpulkan dan menyusun data absensi karyawan PT. Selindo Alpha yang jumlahnya tidak sedikit.

Dengan demikian, dalam kegiatan penelitian ini, penulis mengambil judul penelitian Aplikasi Absensi Karyawan Berbasis Android Dengan Penerapan $Q R$ Code Disertai Foto Diri Dan Lokasi Sebagai Validasi Studi Kasus: PT.Selindo Alpha, sehingga mempermudah dan meringankan tugas HRD (Personalia) dalam menyusun laporan absensi karyawan. Selain itu jika ada karyawan baru, pihak HRD (Personalia) hanya perlu menginputkan data pegawai baru ke dalam sistem, dan pegawai tersebut bisa langsung melakukan absen melalui smartphone mereka.

\section{B. Rumusan Masalah}

Berdasarkan latar belakang yang dijelaskan sebelumnya, maka dapat dirumuskan beberapa permasalahan sebagai berikut:

1. Bagaimana menganalisa alur kerja pada proses input absensi pegawai pada PT. Selindo Alpha?

2. Bagaimana cara membuat otomatisasi sistem absensi pegawai dengan penerapan $Q R$ Code, foto diri dan lokasi pada PT. Selindo Alpha?

3. Bagaimana cara menampilkan dan membuat laporan dari sistem absensi karyawan sehingga lebih tersruktur dan mudah dimonitor?

\section{Tujuan Penelitian}

Berdasarkan rumusan masalah sebelumnya, maka tujuan dari penelitian yang diusulkan adalah sebagai berikut:

1. Menganalisa alur kerja pada proses input absensi pegawai pada PT. Selindo Alpha dengan melakukan proses wawancara dengan pihak Personalia PT. Selindo Alpha.

2. Membangun otomatisasi sistem absensi karyawan berbasis android dengan mengggunakan $Q R$ Code disertai foto diri dan LBS (Location Based System) secara online dengan menggunakan bahasa pemrograman berbasis Java dan DBMS MySql sebagai database nya.

3. Menyediakann fitur yang dapat menampilkan dan membuat laporan dari sistem absensi karyawan sehingga lebih terstruktur dan mudah di monitor pada aplikasi mobile, sehingga karyawan dapat dengan mudah melihat dan mengevaluasi kembali kinerjanya.

\section{Batasan Masalah}

Agar fokus penelitian lebih terarah, jelas dan tidak terlampau luas, maka pada penelitian ini akan dibatasi permasalahan yang dibahas antara lain sebagai berikut:

1. Sistem aplikasi ini dibuat dengan teknologi berbasis operating system android, dimana menggunakan bahasa pemrograman berbasis java.

2. Basis data/database yang digunakan yaitu MySql.

3. Penelitian ini hanya mencakup aktifitas absensi pegawai, proses identifikasi dengan QR Code, menampilkan suatu lokasi, membaca lokasi dari pengguna device, dan menampilkan report dari absensi pegawai.

4. Membatasi akses login dan lokasi absensi.

5. Model pengembangan aplikasi menggunakan Agile Scrum.

\section{LANDASAN TEORI}

\section{A. Android}

Android merupakan sebuah sistem operasi perangkat mobile berbasis Linux. Android juga menyediakan platform open source/terbuka bagi para pengembang atau developer untuk mengembahkan dan menciptakan aplikasi baru buatan mereka sendiri yang nantinya akan digunakan untuk keperluan berbagai macam piranti/device bergerak. ${ }^{[1]}$

\section{B. Java}

Java merupakan bahasa pemrograman berorientasi pada objek (Pemrograman Berbasis Objek) atau biasa dibilang Object Oriented Programming (OOP). Java bersifat netral, maksudnya java itu tidak bergantung pada suatu platform tertentu, melainkan mengikuti prinsip WORA (Write Once and Run Anywhere). ${ }^{[2]}$

\section{Google Maps}

Google Maps adalah layanan atau teknologi pemetaan bumi yang memiliki fitur panorama $360^{\circ}$, pemetaan jalan, rute dan navigasi ke tempat tujuan dengan memanfaatkan citra satelit dalam proses pemetaannya. Pada Google Maps juga dapat digunakan untuk membantu pembuatan layanan pemetaan pada website maupun pada aplikasi berbasis mobile dengan menggunakan 
Google Maps API. Dengan demikian, Google Maps cocok digunakan dalam proses pengembangan atau pembuatan aplikasi sebagai pelengkap fitur pada aplikasi, layaknya sebuah peta.

\section{D. $M y S Q L$}

MySQL merupakan database manajemen sistem yang bersifat relasional database (RDBMS) dan juga bersifat open source (terbuka) dan telah mengadopsi teknologi client-server model. Sedangkan RDBMS sendiri merupakan software/perangkat lunak yang digunakan untuk membuat serta mengelola database berbasiskan pada model relasional database.

\section{E. QR Code}

Quick Response (QR) Code merupakan bentuk/jenis evolusi dari kode batang berupa barcode satu dimensi menjadi kode matriks dalam bentuk dua dimensi yang dikembangkan oleh perusahaan asal Jepang dengan nama DensoWave pada tahun 1994. Sesuai dengan namanya $Q R$ Code bertujuan untuk mendapatkan respon pembacaan data yang lebih cepat dan menyampaikan informasi dengan cepat dan tepat pula.

\section{F. Location Based Service (LBS)}

Location Based Services (LBS) atau layanan berbasis lokasi merupakan sebuah layanan informasi yang bisa diakses dengan perangkat bergerak seperti smartphone melalui jaringan telekomunikasi dan mampu menampilkan posisi letak longitude dan latitude secara geografis mengenai keberadaan dari perangkat bergerak tersebut. ${ }^{[3]}$ Terdapat dua unsur utama dari suatu Location Based Services yaitu:

1. Location Manager (API Maps): Menyediakan perangkat bagi sumber atau source bagi LBS, Application Programming Interface (API) Maps menyediakan fasilitas atau layanan untuk menampilkan maps/peta.

\section{Location Providers (API Location):}

Menyediakan teknologi searcing location atau pencarian lokasi yang digunakan oleh perangkat. API Location yang langsung berhubungan dengan data satelit GPS (Global Positioning System) dan data pemetaan lokasi secara real-time. ${ }^{[4]}$

\section{G. Kehadiran}

Absensi merupakan suatu aktifitas pendataan kehadiran, dan juga bagian dari pelaporan aktifitas suatu institusi, atau komponen pada institusi itu sendiri yang berisi data-data dari aktifitas kehadiran yang disusun atau diatur sedemikian rupa, sehingga mudah untuk dilalukan pencarian dan juga mudah untuk dipergunakan kembali datanya apabila sewaktu-waktu diperlukan oleh pihak manajemen yang berkepentingan.

\section{METODE PENELITIAN}

\section{A. Tahapan Penelitian}

Pada penelitian ini, tahapan penelitian dimulai dari identifikasi masalah dari studi kasu yang ada, perumusan masalah dengan merumuskan permasalahan pada studi kasus, pengumpulan data dengan studi literatur dan mencari penelitian sejenis, pembuatan sistem dengan bantuan pengembangan sistem dengan metode scrum, serta pengujian sistem yang telah dibangun dengan melakukan blackbox testing, adapun tahapan penelitiannnya sebagai berikut.

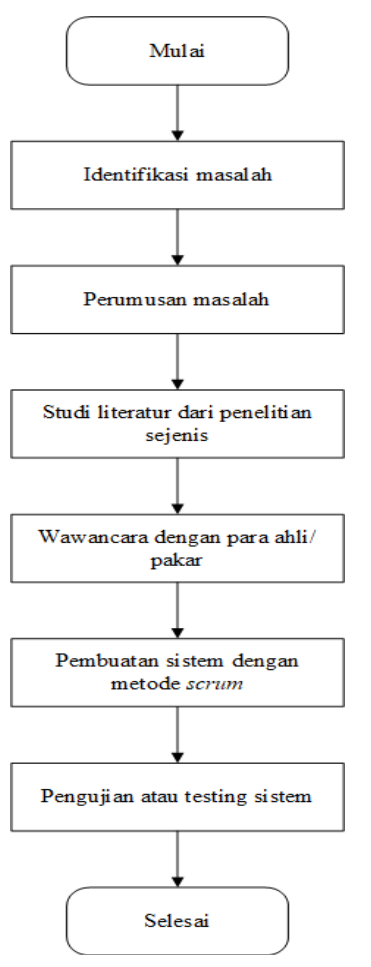

Gambar 1. Tahapan Penelitian

B. Metode Pengembangan Sistem 


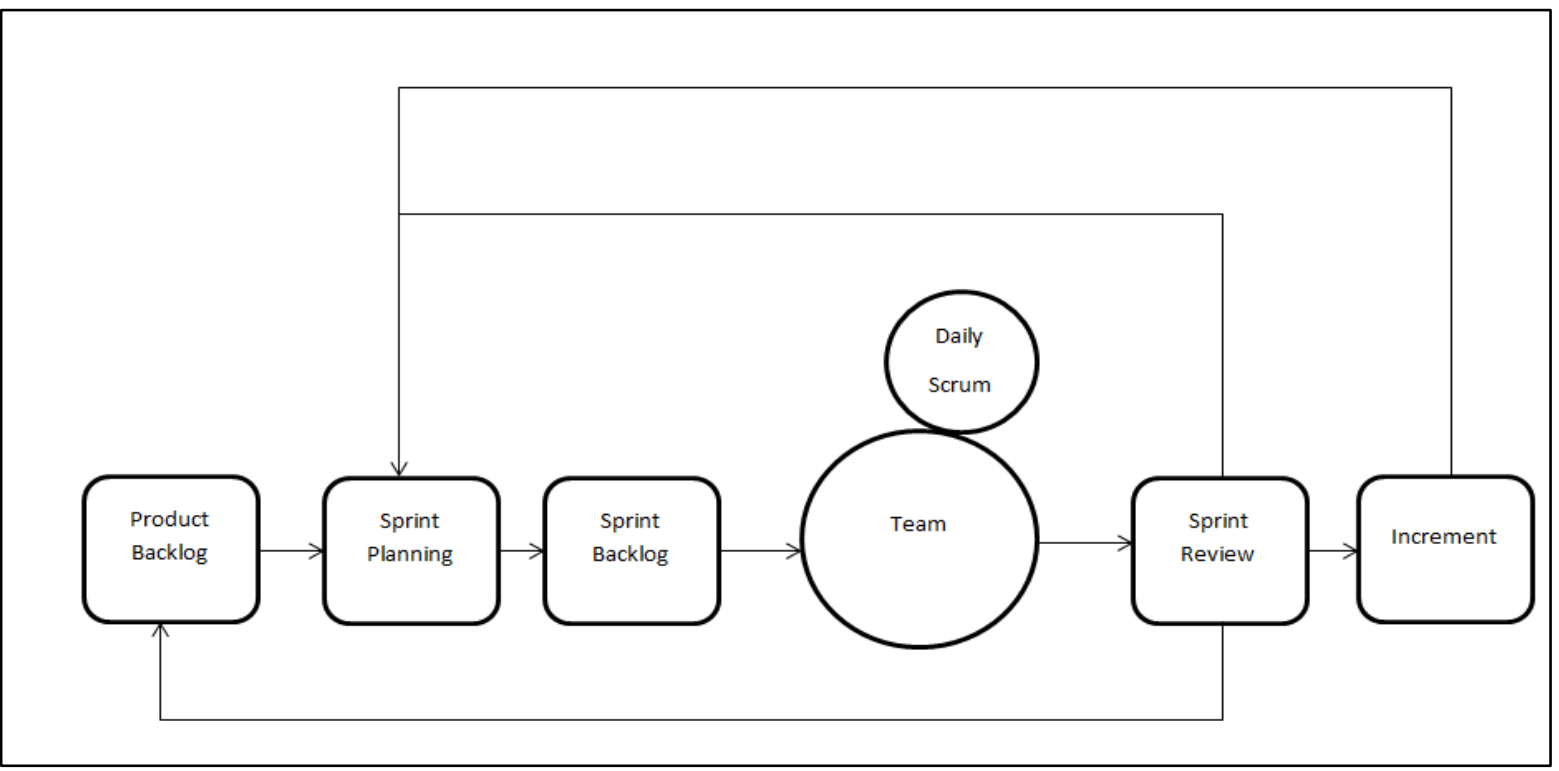

Gambar 2. Model Scrum

Metode penelitian yang digunakan dalam pembuatan aplikasi ini adalah model scrum. Model scrum merupakan metode pengembangan perangkat lunak secara cepat (agile). Prinsip kerja model scrum sesuai dengan prinsip-prinsip yang diterapkan pada metode pengembangan perangkat lunak secara cepat yang digunakan untuk mengarahkan kegiatan pengembangan perangkat lunak, seperti pemenuhan kebutuhan atau requirement, analisa sistem, desain sistem, dan penyampaian (delivery). Rangkaian dalam model scrum terdiri dari:

1. Product Backlog.

Pada tahap ini, pemilik atau konsumen produk dari aplikasi membuat list/daftar keinginan yang akan dijadikan prioritas untuk dilaksanakan.

2. Sprint Planning.

Selama proses perencanaan pada tahap sprint, tim harus memilih salah satu item dari urutan dengan posisi teratas pada daftar keinginan tersebut, selanjutnya memutuskan bagaimana mereka dapat menjalankan potongan tersebut.

3. Sprint Backlog.

Seiring dengan sprint berikutnya akan dilaksanakan, kemudian tim memilih item lain lagi dari produk backlog, lalu melanjutkan perkerjaannya kembali.

4. Daily Scrum/Scrum Meeting.

Tim pengembang memiliki sejumlah waktu, yang biasa disebut dengan istilah sprint (lama prosesnya, biasanya berkisar antara dua sampai empat minggu) untuk proses penyelesaian pekerjaannya, akan tetapi setiap harinya akan dilakukan proses pengecekan untuk melihat status atau progres dari setiap pekerjaan.

5. Sprint Review.

Pada akhir sprint, setiap proses pekerjaan harus berpotensi untuk dikirim dan siap untuk diserahkan kepada pelanggan, biasanya akan diletakkan di lokasi tertentu, atau ditunjukkan kepada pemangku kepentingan. Proses sprint diakhiri dengan tahapan review sprint dan retrospektif.

6. Increment.

Pada tahapan ini, akan dilakukan berulang sampai proyek dianggap selesai, baik karena batas waktu atau deadine yang sudah ditentukan atau bahkan masalah keuangan (budged). Pada tahapan ini, melengkapi seluruh daftar item yang sudah ditentukan dari awal.

\section{Tahapan Pengumpulan Data}

Pada penelitian ini, dilakukan dua tahapan dalam mengumpulkan data-data yang diperlukan yaitu:

1. Studi Literatur.

Pada tahapan ini, dilakukan Studi literatur yang berfungsi untuk mengumpulkan berbagai macam referensi dari data dan informasi melalui berbagai macam jenis dokumen, baik berupa buku, artikel jurnal, prosiding dari seminar, laporan-laporan, atau bahkan bentuk lainnya dalam bentuk tercetak maupun digital.

2. Metode Wawancara.

Pada tahapan wawancara dilakukan untuk mendapatkan referensi dari aplikasi yang diinginkan serta mengkonfirmasi dari data 
atau fakta yang didapatkan pada saat observasi, serta sekaligus untuk memperoleh software requirement dari pengguna. Pada tahapan wawancara juga dilakukan wawancara langsung terhadap karyawan PT. Selindo Alpha yang terlibat langsung dalam proses input absensi pegawai.

\section{Waktu dan Lokasi Penelitian}

Penelitian ini dilaksanakan selama periode Juli hingga November 2020. Tempat penelitian untuk pengembangan dan revisi aplikasi dilaksanakan di PT. Selindo Alpha. Serta, pada tahapan uji coba aplikasi dengan menggunakan black box testing dilakukan oleh beberapa orang yang berkompeten melakukan uji coba pada aplikasi.

\section{HASIL DAN PEMBAHASAN}

\section{A. Diagram Sistem}

Fungsi utama dari sistem ini adalah melakukan aktifitas absensi oleh karyawan. Berikut ini merupakan diagram yang menjelaskan secara singkat mengenai alur dan kerja dari aplikasi sistem absensi karyawan berbasis android dengan penerapan $Q R$ Code disertai foto diri dan lokasi sebagai validasi studi kasus: PT.Selindo Alpha. Adapun diagram nya sbb:

\section{Usecase Diagram}

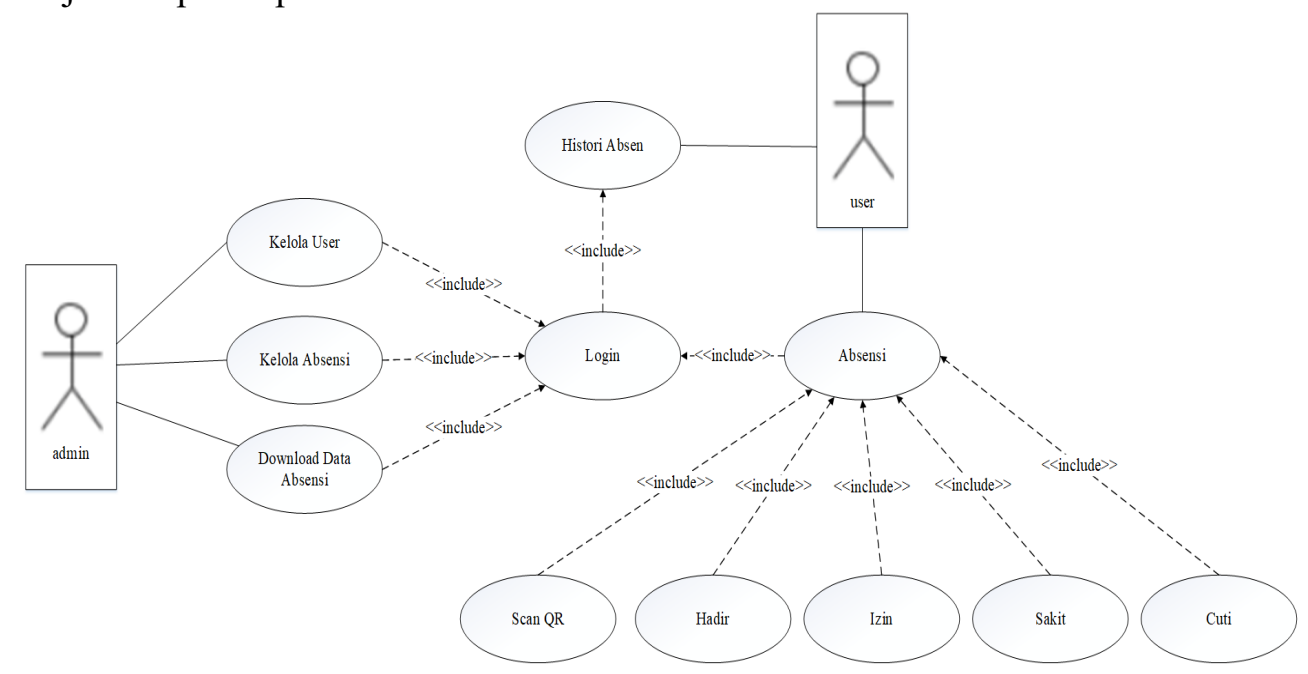

Gambar 3. Use Case Diagram

Dari diagram use case dijelaskan bahwa ketika pengguna login sebagai user, maka pengguna hanya bisa melakukan input absensi dan melihat history absensi yang telah dia lakukan. Disini user bisa melakukan input absensi sesuai dengan pilihannya (scan $Q R$, hadir, izin, sakit dan cuti) dengan memilih menu absensi. Apabila pengguna login sebagai admin, maka pengguna bisa melakukan pengelolaan data user dan absensi tetapi tidak ada menu untuk input absensi. Pada gambar tersebut, <<include $>>$ disini berarti bahwa baik user maupun admin harus login terlebih dahulu agar dapat menjalankan fungsi aplikasi tersebut. Dan untuk user sendiri, harus memilih menu absensi yang tersedia bila ingin 2. Activity Diagram melakukan input absensi. 


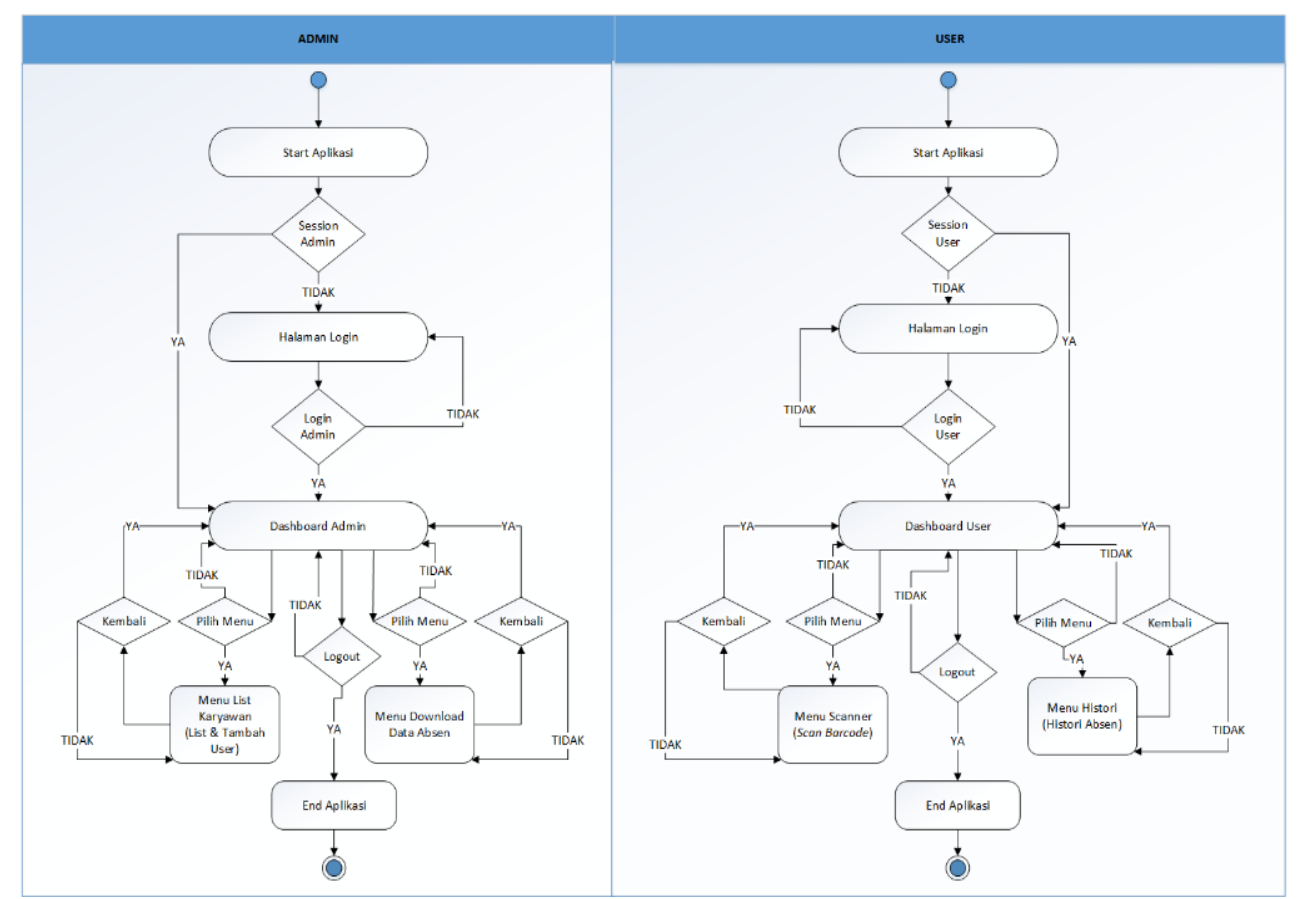

Gambar 3. Activity Diagram

Pada gambar 3 activity diagram dijelaskan perbedaan alur dan fitur pada pengguna user dan admin. Adapun penjelasannya sebagai berikut:

a. Setelah pengguna login sebagai admin maka aplikasi akan menampilkan semua menu dimana admin dapat melakukan tambah, ubah, hapus dan simpan data user serta dapat mendownload.

b. Ketika pengguna login sebagai user, maka aplikasi akan menampilkan sebuah menu scan, absensi dan histori absen, dimana user melakukan input data absen atau bisa dengan cara scan $Q R$ Code. Disini user juga bisa melihat histori dari absen yang sudah user inputkan ke dalam sistem.

c. Setelah proses absensi selesai maka sistem menyimpan data langsung ke dalam database. Ketika data absensi dibutuhkan, dapat di download berupa file berformat pdf oleh admin .

\section{Class Diagram}

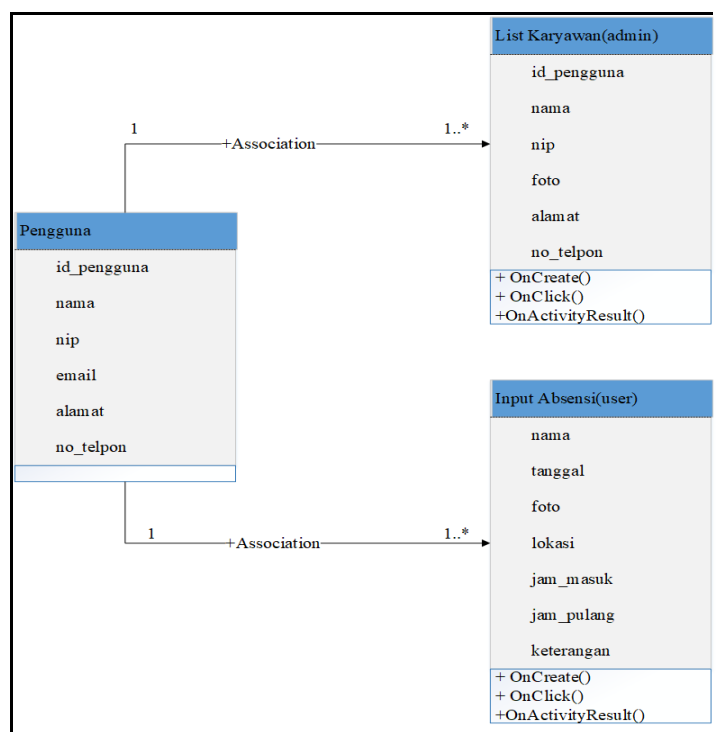

Gambar 4. Class Diagram

Class diagram di atas menjelaskan bahwa ketika aplikasi dibuka akan menampilkan tampilan menu login. Disini pengguna harus input username dan password agar dapat masuk ke dalam tampilan dashboard, dan juga sebagai validasi apakah pengguna login sebagai admin atau user. Setelah berhasil masuk halaman dashboard, pengguna akan melihat beberapa tampilan menu. Admin akan menampilkan menu list karyawan dan download data absensi, sedangkan untuk user akan menampilan menu input absensi, scan QR Code dan history absensi.

\section{Sequence Diagram}




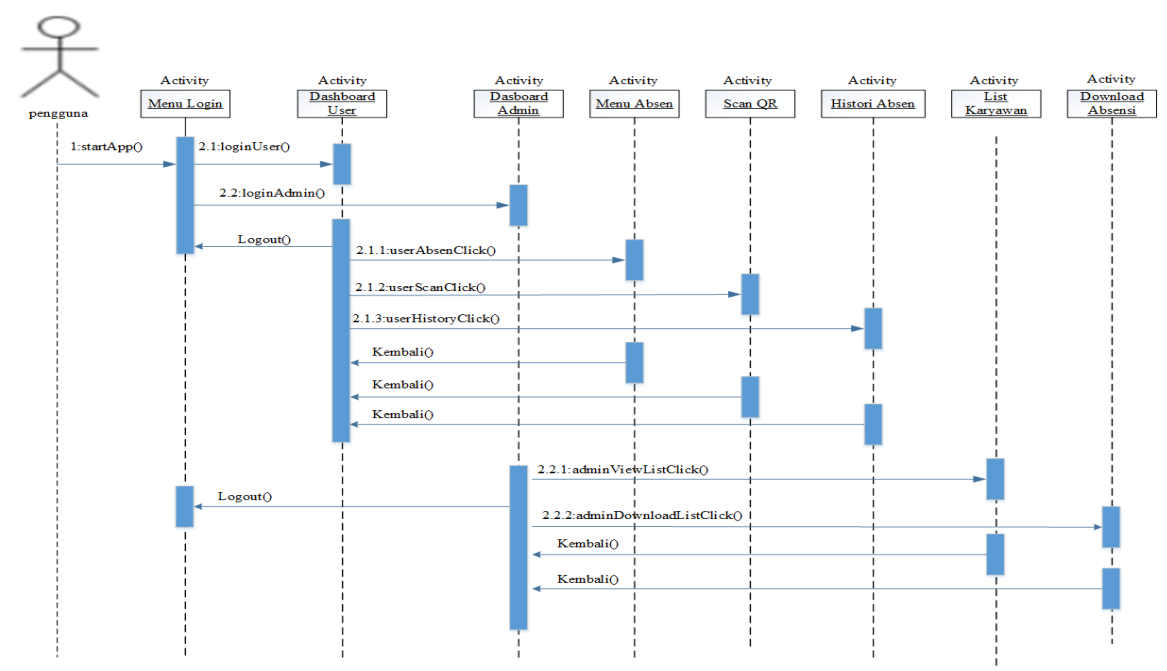

Gambar 5. Sequence Diagram

Pada diagram sequance diatas menggambarkan proses dari karyawan ketika melakukan aktivitas absensi pada aplikasi. Pertama kali karyawan akan melihat tampilan menu login baru setelah itu akan muncul tampilan dashboard. Setelah memilih menu absensi pada dashboard maka karayawan dapat melakukan input absensi pada aplikasi dengan cara menekan tombol submit setelah mengisi data yang diperlukan pada aplikasi. Setelah karwayan menekan tombol submit maka data akan dikirim ke database oleh sistem lalu data akan di validasi oleh database, jika data sudah ter validasi maka karyawan berhasil melakukan absensi.

\section{B. Hasil}

Berikut ini merupakan hasil dari pengujian aplikasi sistem absensi karyawan berbasis android dengan penerapan $Q R$ Code disertai foto diri dan lokasi sebagai validasi studi kasus: PT.Selindo Alpha yang dilakukan pada smartphone Android dengan spesifikasi android 10:

\section{Antarmuka Halaman Login}

Pada halaman login berisi tampilan awal saat membuka aplikasi sistem absensi karyawan berbasis android dengan penerapan $Q R$ Code disertai foto diri dan lokasi sebagai validasi studi kasus: PT.Selindo Alpha. Disini pengguna memasukkan username dan password agar dapat melanjutkan ke halaman berikutnya dan menentukan posisi login sebagai user atau admin. Berikut halaman login pada aplikasi ini:

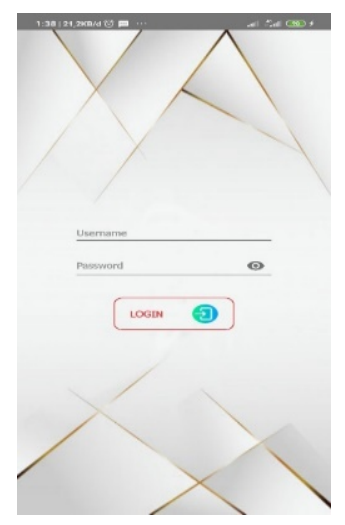

Gambar 6. Antarmuka Halaman Login

2. Antarmuka Halaman Dashboard Admin

Pada halaman dashboard admin terdapat tiga pilihan menu utama yaitu download absensi, List Karyawan, dan Logout. Berikut halaman dashboard pada aplikasi ini:

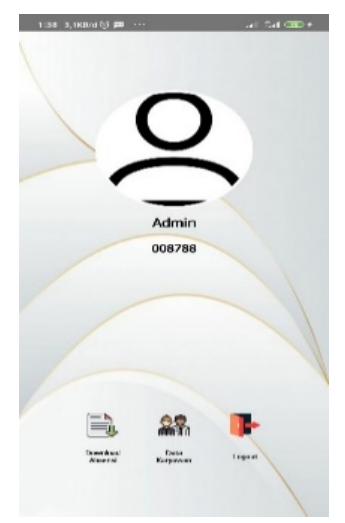

Gambar 7. Antarmuka Halaman Dashboard Admin

3. Antarmuka Halaman Download Absensi

Pada halaman ini aplikasi akan menampilkan tabel list absensi dari database dan dapat mengunduh data tersebut ke dalam memori 
internal perangkat dalam format pdf. Berikut halaman download absensi pada aplikasi ini:

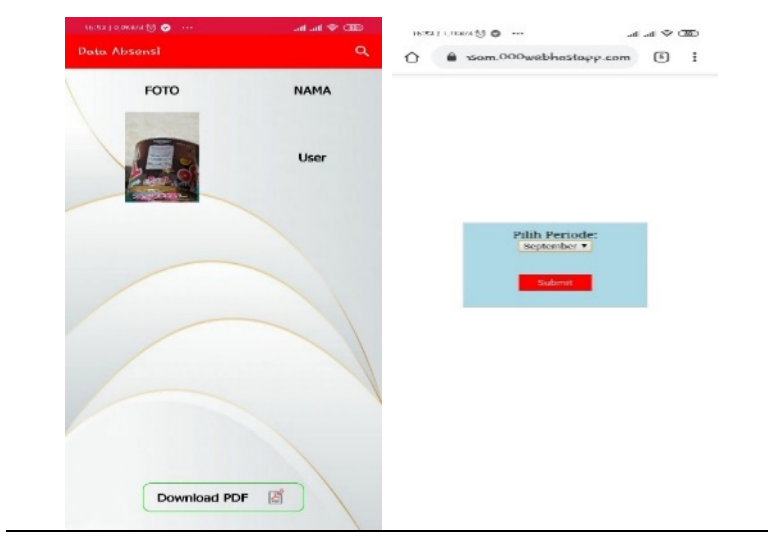

Gambar 8. Antarmuka Halaman Download Absensi

\section{Antarmuka Halaman List Karyawan}

Menu list karyawan menampilkan dua tab menu yaitu tab list user dan tab tambah user. Berikut ini merupakan tampilan dari halaman list karyawan:

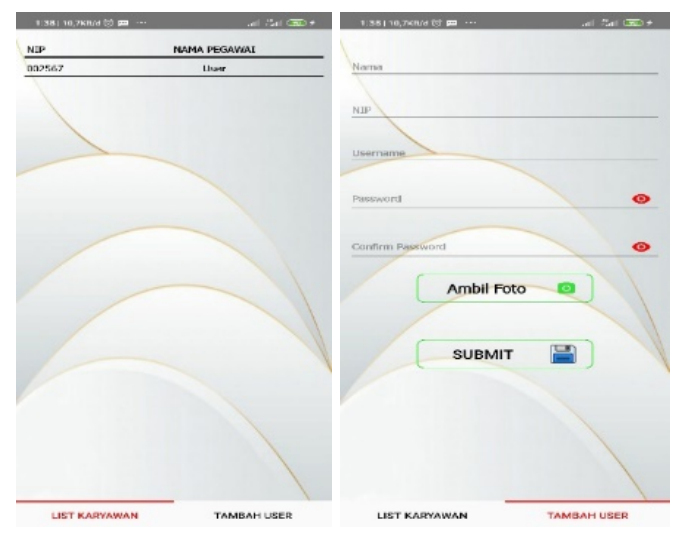

Gambar 9. Antarmuka Halaman List Karyawan

\section{Antarmuka Halaman Dashboard User}

Menu dashboard user memiliki empat menu utama yaitu Scan, Absensi, Histori, dan Logout. Berikut ini merupakan tampilan dari halaman dashboard user pada gambar 10.

\section{Antarmuka Halaman Menu Scan}

Menu Scan bertujuan untuk menampilkan halaman aktifitas memindai barcode untuk melakukan input absensi. Berikut merupakan tampilan menu Scan pada aplikasi ditunjukkan pada gambar 11.

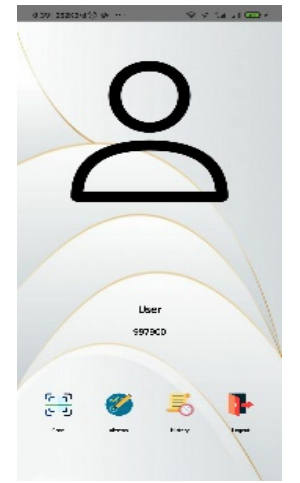

Gambar 10. Antarmuka Halaman Menu Dashboard User
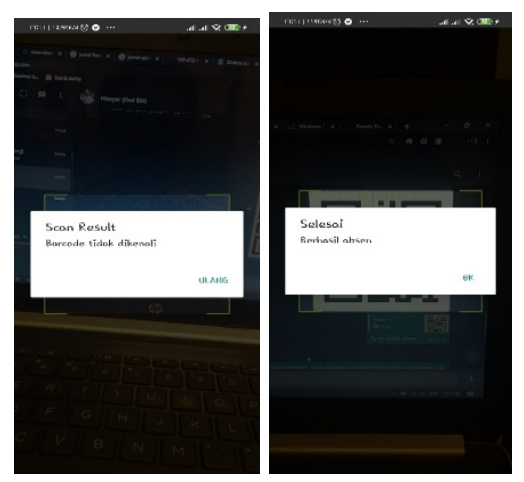

Gambar 11. Antarmuka Halaman Menu Scan

\section{Antarmuka Halaman Menu Absensi}

Menu Absensi bertujuan untuk menampilkan tampilan input absensi secara manual yang berisikan tanggal, foto diri, jam, dan lokasi. Pada menu absensi terdapat dua pilihan tab utama yaitu tab hadir dan tab berhalangan. Berikut tampilan menu Absensi pada aplikasi ini:

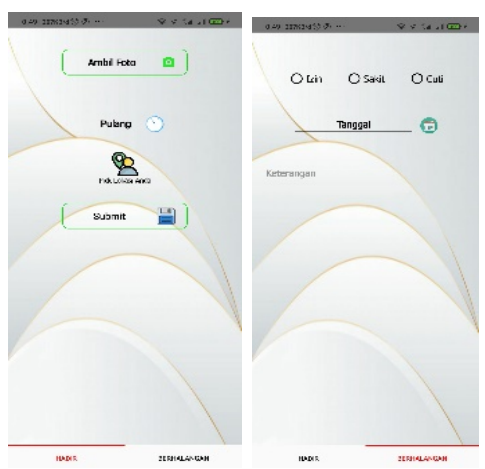

Gambar 12. Antarmuka Halaman Menu Absensi

\section{Antarmuka Halaman Menu Histori}

Menu Histori bertujuan untuk menampilkan informasi riwayat absensi yang sudah diinput user 
ke dalam database. Berikut merupakan tampilan dari halaman menu histori:

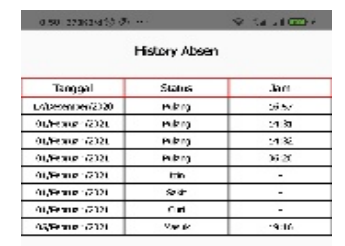

Gambar 13. Antarmuka Halaman Menu Histori

\section{Hasil Pengujian BlackBox}

Pengujian terhadap sistem yang dibuat dilakukan dengan metode pengujian black box pada aplikasi sistem absensi karyawan berbasis android dengan penerapan $Q R$ Code disertai foto diri dan lokasi sebagai validasi studi kasus: PT.Selindo Alpha. Berikut ini table dari pengujian Black Box:

Tabel 1. Hasil Pengujian BlackBox Untuk Admin

\begin{tabular}{|c|c|c|c|c|c|}
\hline $\begin{array}{l}\mathrm{N} \\
\mathrm{O}\end{array}$ & $\begin{array}{c}\text { Kelas } \\
\text { Uji }\end{array}$ & $\begin{array}{c}\text { Daftar } \\
\text { Pengujian }\end{array}$ & $\begin{array}{c}\text { Kasus } \\
\mathrm{Uji}\end{array}$ & $\begin{array}{l}\text { Hasil yang } \\
\text { diharapkan }\end{array}$ & $\begin{array}{c}\text { Valid } \\
(\checkmark) \\
\text { atau } \\
\text { Tidak } \\
\text { Valid } \\
(\mathrm{x}) \\
\end{array}$ \\
\hline 1 & Login & $\begin{array}{l}\text { Input data } \\
\text { login }\end{array}$ & $\begin{array}{l}\text { Userna } \\
\text { me = } \\
\text { admin } \\
\text { Passwo } \\
\text { rd = } \\
\text { admin, } \\
\text { klik } \\
\text { tombol } \\
\text { login }\end{array}$ & $\begin{array}{l}\text { Masuk ke } \\
\text { halaman } \\
\text { dashboard } \\
\text { admin } \\
\text { aplikasi }\end{array}$ & $\checkmark$ \\
\hline \multirow[b]{2}{*}{$\begin{array}{l}2 \\
.\end{array}$} & \multirow{2}{*}{$\begin{array}{l}\text { Fungsi } \\
\text { pada } \\
\text { menu } \\
\text { Data } \\
\text { Karya } \\
\text { wan }\end{array}$} & $\begin{array}{l}\text { Pengujian } \\
\text { menampilk } \\
\text { an halaman } \\
\text { data } \\
\text { karyawan }\end{array}$ & $\begin{array}{l}\text { Admin } \\
\text { memili } \\
\text { h menu } \\
\text { Data } \\
\text { Karya } \\
\text { wan }\end{array}$ & $\begin{array}{l}\text { Tampil } \\
\text { halaman } \\
\text { data } \\
\text { karyawan }\end{array}$ & $\checkmark$ \\
\hline & & $\begin{array}{l}\text { Tambah } \\
\text { Data } \\
\text { Karyawan }\end{array}$ & $\begin{array}{l}\text { Admin } \\
\text { memas } \\
\text { ukkan } \\
\text { data } \\
\text { karyaw } \\
\text { an } \\
\text { dengan } \\
\text { lengka } \\
\text { p dan }\end{array}$ & $\begin{array}{l}\text { Menampilk } \\
\text { an data } \\
\text { yang sudah } \\
\text { ditambahka } \\
\text { n dan data } \\
\text { tersimpan } \\
\text { pada } \\
\text { database }\end{array}$ & $\checkmark$ \\
\hline
\end{tabular}

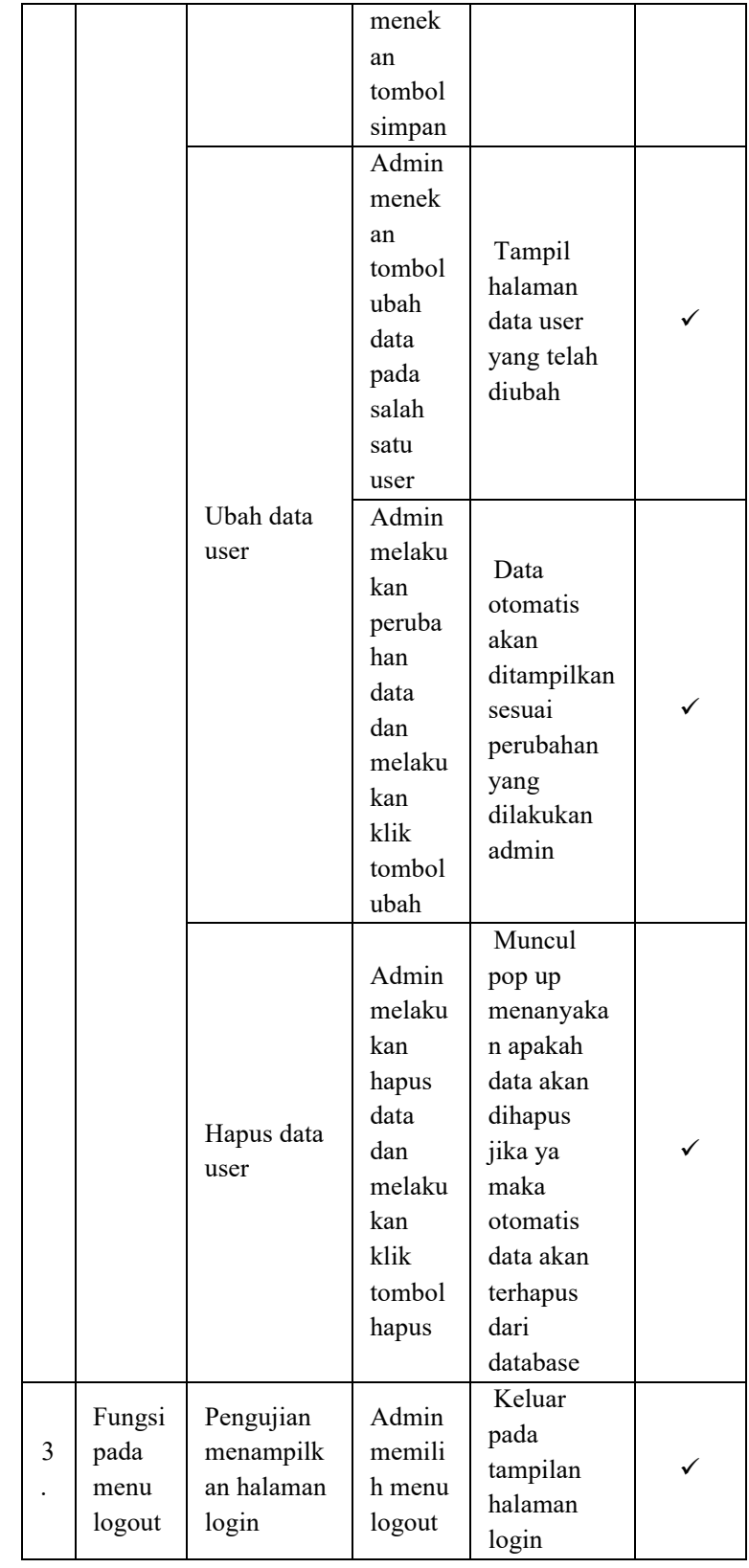

Tabel 2. Hasil Pengujian BlackBox Untuk User

\begin{tabular}{|c|c|c|c|c|c|}
\hline No & $\begin{array}{c}\text { Kelas } \\
\text { Uji }\end{array}$ & $\begin{array}{c}\text { Daftar } \\
\text { Pengujian }\end{array}$ & $\begin{array}{c}\text { Kasus } \\
\text { Uji }\end{array}$ & $\begin{array}{l}\text { Hasil yang } \\
\text { diharapkan }\end{array}$ & $\begin{array}{c}\text { Vali } \\
\text { d } \\
(\checkmark) \\
\text { atau } \\
\text { Tida } \\
\text { k } \\
\text { Vali } \\
\text { d (x) }\end{array}$ \\
\hline 1. & Login & $\begin{array}{l}\text { Input data } \\
\text { login }\end{array}$ & $\begin{array}{l}\text { Usernam } \\
\text { e = user } \\
\text { Password } \\
=\text { user, } \\
\text { klik } \\
\text { tombol } \\
\text { login }\end{array}$ & $\begin{array}{l}\text { Masuk ke } \\
\text { halaman } \\
\text { dashboard } \\
\text { user } \\
\text { aplikasi }\end{array}$ & $\checkmark$ \\
\hline 2. & $\begin{array}{l}\text { Fungsi } \\
\text { pada } \\
\text { menu } \\
\text { Scan }\end{array}$ & $\begin{array}{l}\text { Pengujian } \\
\text { melakukan } \\
\text { absensi } \\
\text { dengan }\end{array}$ & $\begin{array}{l}\text { User } \\
\text { melakuka } \\
\text { n scan } \\
\text { Barcode } \\
\text { untuk }\end{array}$ & $\begin{array}{l}\text { Melakukan } \\
\text { proses } \\
\text { absensi dan } \\
\text { menyimpan } \\
\text { data }\end{array}$ & $\checkmark$ \\
\hline
\end{tabular}




\begin{tabular}{|c|c|c|c|c|c|}
\hline & & $\begin{array}{l}\text { scan } \\
\text { Barcode }\end{array}$ & $\begin{array}{l}\text { input } \\
\text { absensi }\end{array}$ & $\begin{array}{l}\text { absensi } \\
\text { pada } \\
\text { database. }\end{array}$ & \\
\hline \multirow{3}{*}{2.} & \multirow{3}{*}{$\begin{array}{l}\text { Fungsi } \\
\text { pada } \\
\text { menu } \\
\text { Absen }\end{array}$} & $\begin{array}{l}\text { Pengujian } \\
\text { menampilk } \\
\text { an halaman } \\
\text { Absensi }\end{array}$ & $\begin{array}{l}\text { User } \\
\text { memilih } \\
\text { menu } \\
\text { Absensi }\end{array}$ & $\begin{array}{l}\text { Tampil } \\
\text { halaman } \\
\text { Absensi }\end{array}$ & $\checkmark$ \\
\hline & & $\begin{array}{l}\text { Input } \\
\text { Absen } \\
\text { Hadir }\end{array}$ & $\begin{array}{l}\text { User } \\
\text { memasuk } \\
\text { kan data } \\
\text { absensi } \\
\text { dengan } \\
\text { lengkap } \\
\text { (hadir) } \\
\text { dan } \\
\text { menekan } \\
\text { tombol } \\
\text { submit }\end{array}$ & $\begin{array}{l}\text { Memproses } \\
\text { absensi dan } \\
\text { data } \\
\text { tersimpan } \\
\text { pada } \\
\text { database }\end{array}$ & $\checkmark$ \\
\hline & & $\begin{array}{l}\text { Input } \\
\text { Absen } \\
\text { Berhalanga } \\
\mathrm{n}\end{array}$ & $\begin{array}{l}\text { User } \\
\text { memasuk } \\
\text { kan data } \\
\text { absensi } \\
\text { dengan } \\
\text { lengkap } \\
\text { (izin, } \\
\text { sakit, } \\
\text { cuti) dan } \\
\text { menekan } \\
\text { tombol } \\
\text { submit }\end{array}$ & $\begin{array}{l}\text { Memproses } \\
\text { absensi dan } \\
\text { data } \\
\text { tersimpan } \\
\text { pada } \\
\text { database }\end{array}$ & $\checkmark$ \\
\hline 3. & $\begin{array}{l}\text { Fungsi } \\
\text { pada } \\
\text { menu } \\
\text { History } \\
\text { Absen }\end{array}$ & $\begin{array}{l}\text { Pengujian } \\
\text { menampilk } \\
\text { an halaman } \\
\text { histori } \\
\text { Absensi }\end{array}$ & $\begin{array}{l}\text { User } \\
\text { memilih } \\
\text { menu } \\
\text { History } \\
\text { Absensi }\end{array}$ & $\begin{array}{l}\text { Tampil } \\
\text { halaman } \\
\text { History } \\
\text { Absensi } \\
\text { dan } \\
\text { menampilk } \\
\text { an data } \\
\text { yang } \\
\text { tersimpan } \\
\text { pada } \\
\text { database }\end{array}$ & $\checkmark$ \\
\hline 4. & $\begin{array}{l}\text { Fungsi } \\
\text { pada } \\
\text { menu } \\
\text { logout }\end{array}$ & $\begin{array}{l}\text { Pengujian } \\
\text { menampilk } \\
\text { an halaman } \\
\text { login }\end{array}$ & $\begin{array}{l}\text { Admin } \\
\text { memilih } \\
\text { menu } \\
\text { logout }\end{array}$ & $\begin{array}{l}\text { Keluar } \\
\text { pada } \\
\text { tampilan } \\
\text { halaman } \\
\text { login }\end{array}$ & $\checkmark$ \\
\hline
\end{tabular}

10. Kelebihan Dan Kekurangan Aplikasi

Kelebihan dari aplikasi ini adalah:

a. Waktu yang dibutuhkan pegawai untuk input absen menjadi lebih singkat.

b. Meringankan pekerjaan pegawai dalam rekap absensi bulanan.

c. Meminimalisir terjadinya titip absen pada pegawai.

d. Range lokasi absen ditentukan, sehingga user tidak bisa absen pada sembarang lokasi.

Kekurangan dari aplikasi ini adalah: a. Harus menambahkan lokasi secara manual dalam database ketika ada lokasi kantor cabang baru.

b. Tidak adanya alert/notifikasi ketika user terlambat untuk input absen.

c. Tidak ada fitur pengajuan cuti berbasis android dalam aplikasi.

\section{KESIMPULAN DAN SARAN}

\section{A. Kesimpulan}

Berdasarkan pembahasan dan hasil yang diperoleh, maka dapat ditarik beberapa poin kesimpulan sebagai berikut:

1. Aplikasi berbasis android dapat digunakan di area lokasi manapun yang sudah terdaftar dalam database dan kapanpun tanpa harus mengisi form absensi ke kantor terlebih dahulu.

2. Aplikasi absensi berbasis android ini dapat mempermudah dalam proses pengolahan data absensi pada PT Selindo Alpha.

3. Pengguna baru lebih cepat memahami alur penggunaan aplikasi ini karena fungsi pada aplikasi sangat mudah dipahami.

4. Aplikasi ini dilengkapi dengan hak akses yang berbeda dimana admin dapat mengelola dan menambahkan user login dan mengunduh data absensi ke dalam file berformat .pdf.

5. Aplikasi absensi berbasis android ini mengggunakan android_id masing-masing perangkat, sehingga tidak dapat sembarang masuk melalui perangkat yang berbeda.

6. Dengan dilakukannya demo secara langsung dan pengetesan yang dilakukan oleh 10 pengguna aplikasi di lingkungan PT Selindo Alpha, maka didapat hasil yang valid untuk semua skenario testing yang dilakukan. Hasil pengujian aplikasi menggunakan metode pengujian Black Box pada sistem menunjukkan bahwa sistem mempunyai tingkat fungsionalitas yang baik, semua fungsi yang berada pada sistem dapat bekerja dengan baik.

\section{B. Saran}

Sistem ini masih memiliki banyak keterbatasan dan kekurangan, sehingga dibutuhkan beberapa saran membangun diantaranya:

1. Aplikasi sistem absensi karyawan berbasis android dengan penerapan $Q R$ Code disertai foto diri dan lokasi sebagai validasi studi kasus: PT. Selindo Alpha dapat dikembangkan untuk berbagai sistem operasi mobile guna 
meningkatkan tingkat efisiensi dari aplikasi ini.

2. Aplikasi sistem absensi karyawan berbasis android dengan penerapan $Q R$ Code disertai foto diri dan lokasi sebagai validasi studi kasus: PT. Selindo Alpha dapat dikembangkan dengan penambahan fitur keamanan deteksi wajah, guna meningkatkan tingkat keamanan dari aplikasi absensi ini.

3. Aplikasi sistem absensi karyawan berbasis android dengan penerapan $Q R$ Code disertai foto diri dan lokasi sebagai validasi studi kasus: PT. Selindo Alpha dapat dikembangkan dengan menambahkan fitur pengajuan cuti menggunakan aplikasi mobile, guna meningkatkan tingkat efektifitas dari aplikasi absensi ini, serta menambahkan fitur add location pada dashboard admin, guna meningkatkan fungsionalitas dari aplikasi absensi ini.

\section{DAFTAR PUSTAKA}

[1] Christenssion, P. Android Definition. TechTerms: 16 Mei 2018.

[2] Siallagan, S. Pemrograman Java: dasar-dasar pengenalan dan pemahaman / Sariadin Siallagan. Yogyakarta: 2009.

[3] Purbojati, Rikky Wenang. Implementasi Location Based Service. Universitas Indonesia, Jakarta: 2004.

[4] Jogiyanto, Metodologi Penelitian Sistem Informasi. Yogyakarta: Andi, 2008.

[5] Sugiono, Penelitian dan Pengembangan (Research and Development/R\&D). Bandung: Penerbit Alfabeta, 2015.

[6] A. A. R. Onny, D. Danur, I. N. Piarsa, and A. A. K. O. Sudana, "Rancang Bangun Aplikasi
Absensi Mahasiswa pada Platform Android," vol. 4, no. 1, pp. 72-81, 2016.

[7] D. I. P. Informasi and B. K. Sekolah, "PENGEMBANGAN APLIKASI ABSENSI SISWA BERBASIS ANDROID," vol. 10, no. 01, pp. 55-68, 2020.

[8] P. A. Sunarya, E. Febriyanto, and J. Januarini, "Aplikasi Mobile Absensi Karyawan Dan Pengajuan Cuti Berbasis GPS," vol. 12, no. 2, pp. 241-247, 1978.

[9] S. Kasus and S. M. P. Negeri, "Aplikasi Guru Pada Sekolah Berbasis Android(Studi Kasus: SMP Negeri 1 Bulukumba)," pp. 1-80, 2018.

[10]L. Based, S. Lbs, and B. Android, "Aplikasi Absensi Tenaga Marketing Mengggunakan Metode Location Based Service (LBS) Berbasis Adroid (Studi Kasus: PT. Unichem Candi Indonesia)".

[11]S. A. Khoir, A. Yudhana, T. Informatika, T. Elektro, and U. A. Dahlan, "Implementasi GPS (Global Positioning System) Pada Presensi Berbasis Android Di BMT Insan Mandiri," vol. 4, pp. 9-17, 2020.

[12]P. O. Box, "Sistem Absensi Asisten Dosen Menggunakan QR Code Scanner Berbasis Android Pada Program Studi Sistem Informasi, Fakultas Teknik, Universitas Muria Kudus,” pp. 303-310, 2015.

[13]T. H. E. Utilization et al., "Pemanfaatan QR Code Dalam Memudahkan Proses Absensi," 2019.

[14]L. P. I. Garut, "Pembuatan absensi berbasis android menggunakan metode waterfall untuk program studi pendidikan teknologi informasi ipi garut."

[15]B. B. Sumolong et al., "Aplikasi Absensi Jemaat Berbasis Android," vol. 13, no. 2, 2018. 